\title{
POLA DESKRIPSI PADA ISTILAH BUDAYA BALI DALAM TEKS BERBAHASA INGGRIS
}

\author{
Ni Ketut Alit Ida Setianingsih \\ Program Studi Sastra Inggris, Fakultas Ilmu Budaya, Universitas Udayana \\ Jl. Pulau Nias no. 13 Denpasar, 80113, Telp. (0361) 257415 \\ alit_ida@yahoo.com
}

\begin{abstract}
ABSTRAK
Artikel ini membahas mengenai pola deskripsi yang digunakan pada penggunaan istilah budaya Bali dalam teks berbahasa Inggris. Teks bermuatan budaya menjadi salah satu tantangan dalam komunikasi. Hal itu mengingat pemahaman budaya turut berperan dalam kelancaran komunikasi. Sehingga memahami budaya menjadi keharusan untuk mempermudah komunikasi antar dua penutur berbeda. Dalam hal ini, teks - teks berbahasa Inggris yang memaparkan mengenai budaya Bali mempunyai tantangan tersendiri. Memberikan pemahaman makna terhadap suatu istilah budaya Bali terhadap pembaca dengan latar budaya yang sangat berbeda. Untuk itu, penambahan informasi dilakukan oleh penulis dan salah satunya dengan menggunakan pola deskripsi. Pola deskripsi memberikan peluang pemahaman yang lebih komprehensif terhadap istilah - istilah budaya yang tidak terdapat kesepadanannya pada budaya lainnya. Sumber data yang digunakan adalah media online dan data yang diambil merupakan teks - teks berisikan istilah budaya Bali yang berbahasa Inggris. Metode pengumpulan data menggunakan metode dokumentasi dengan menerapkan teknik membaca rinci, pencatatan, dan pemilahan data. Sedangkan metode deskriptif kualitatif diaplikasikan untuk menjelaskan pola deskripsi yang terhadap pada penjelasan istilah budaya Bali dalam teks Bahasa Inggris. Simpulan yang diperoleh adalah pola deskripsi menjadi pilihan untuk menjelaskan makna suatu istilah budaya Bali. Dalam upaya menjelaskan makna tersebut, penulis menggunakan pola deskripsi berupa deskripsi bentuk, deskripsi fungsi, maupun kombinasi keduanya. Hanya pada istilah budaya Bali di media online berbahasa Inggris, pola deskripsi bentuk lebih cenderung dominan untuk menjelaskan makna suatu istilah budaya Bali.
\end{abstract}

Kata kunci:pola deskripsi, istilah Bali, teks Bahasa Inggris

\section{PENDAHULUAN}

Persoalan bahasa menjadi permasalahan pelik mengingat bahasa adalah representasi budaya. Bahasa mewakili suatu kelompok atau golongan masyarakat dan hanya golongan atau kelompok itu yang dapat memahami dan memaknai bahasa yang digunakan. Pembatasan antar kelompok atau golongan masyarakat tentunya tidak sesuai dengan semangat komunikasi global. Komunikasi global melibatkan berbagai golongan atau kelompok masyarakat sehingga pembatasan menjadi penghalang dalam komunikasi global. Untuk itulah bahasa Inggris saat ini menjadi salah satu kekuatan bahasa yang dipahami hampir sebagian besar masyarakat dunia. Komunikasi global saat ini merupakan komunikasi yang tiada mengenal batasan. Batasan - batasan seperti wilayah, negara, golongan, ras, dan lainnya tidak lagi menjadi pembatasan dalam sebuah pergaulan internasional. Kehadiran teknologi canggih dengan ditunjang pengetahuan yang memadai sangat memungkinkan hal tersebut. Sehingga seseorang tidak perlu mempertimbangkan banyak hal dalam berkomunikasi dengan rekan - rekannya dari latar belakang wilayah, negara, maupun daerah tertentu. Dalam menjalin komunikasi global tersebut hanya terdapat satu tantangan. Tantangan yang dimaksud adalah tantangan media untuk berkomunikasi. Media berupa bahasa yang dikenal secara internasional menjadi suatu keharusan untuk dapat menjembatani komunikasi antar bangsa.

Bahasa Inggris membuka kesempatan untuk saling mengenal dan memahami budaya beberapa kelompok masyarakat. Bahasa Inggris menjadi media penghubung antar satu kelompok masyarakat dan kelompok masyarakat lainnya. Penggunaan bahasa Inggris juga memungkinkan berfungsi untuk mengenalkan budaya suatu masyarakat ke dunia internasional. Apalagi jika dikaitkan dengan kekhasan atau karakteristik suatu budaya masyarakat. Dalam hal ini, kekhasan maupun karakteristik budaya suku, agama, golongan, maupun ras tertentu dapat disebarluaskan dalam bentuk informasi seperti istilah - istilah budaya. Salah satu contohnya adalah istilah budaya Bali dalam teks berbahasa Inggris. 
Istilah budaya Bali merupakan istilah yang sangat dekat dengan masyarakat Bali. Seperti yang disampaikan oleh Newmark (1988: 95), istilah budaya mempunyai sejumlah klasifikasi mulai dari ekologi, budaya materi (pakaian, perumahan, makanan, transportasi), budaya sosial, penanda dan kebiasaan, serta organisasi, adat istiadat, prosedur, konsep, serta aktivitas aktivitas yang berhubungan dengan media. Dalam komunikasi global sangat dimungkinkan istilah budaya Bali yang dipublikasikan dalam teks - teks bahasa Inggris dengan tujuan pembaca asing. Nantinya pembaca asing memperoleh deskripsi atau penjelasan terkait istilah budaya Bali. Tentunya dengan mempertimbangkan kekhasan istilah budaya Bali, salah satu yang paling penting dalam teks adalah upaya untuk memberikan penjelasan atau informasi penjelas. Dalam hal ini adalah pola deskripsi yang digunakan bertujuan untuk memaparkan secara lebih rinci istilah istilah budaya Bali.

\section{KAJIAN PUSTAKA DAN LANDASAN TEORI}

Terdapat sejumlah literatur yang menjadi acuan pada artikel ini. Literatur - literatur tersebut memberikan pemahaman dan wawasan terkait dengan teknik - teknik untuk mengalihkan makna istilah - istilah budaya yang digunakan pada budaya lain. Setianingsih (2003). Dalam tesisnya yang berjudul Some Alternative Ways of Establishing Lexical Equivalences of Balinese Cultural Terms in English disimpulkan adanya upaya - upaya yang dilakukan oleh pengalihbahasa dalam mencapai kesepadanan alami atau idiomatis. Dengan menggunakan data istilah budaya Bali dalam dua bahasa pada buku kegiatan Pesta Kesenian Bali terdapat upaya atau teknik yang digunakan untuk menemukan kesepadanan istilah budaya Bali sebagai BSu (bahasa sumber) ke dalam bahasa Inggris sebagai BSa (bahasa sasaran). Alternatif - alternatif teknik dalam alih bahasa sesungguhnya merupakan upaya mencapai kesepadanan yang hampir sama pada BSu pada pembaca BSa. Disimpulkan bahwa tujuan aplikasi teknik alternatif sebagai usaha agar pembaca $\mathrm{BSa}$ dapat memahami istilah budaya yang sedang dibacanya dan tidak mengalami kesulitan untuk menafsirkan makna yang terkandung pada istilah budaya BSu. Secara umum, istilah - istilah budaya yang muncul biasanya berkaitan dengan penggunaan istilah yang umum atau khusus maupun dengan menggunakan frasa deskripsi.
Parthama (2006) dalam tesisnya yang berjudul The Translation of Balinese Religious Terms mengungkapkan adanya upaya untuk mempertahankan makna dalam alih bahasa istilah - istilah keagamaan pada konsep Hindu ke dalam bahasa Inggris. Hal ini tentunya sejalan dengan pemahaman mengenai alih bahasa pada umumnya. Apalagi berkaitan dengan alih bahasa budaya yang begitu dekat dengan suatu kelompok masyarakat dan dialihbahasakan ke dalam bahasa lain yang juga dekat dengan kelompok masyarakat berbeda. Yang paling menjadi perhatian adalah adanya spesifikasi khusus pada istilah keagamaan Bali yang selanjutnya dialihbahasakan ke dalam bahasa Inggris. Hal ini tentunya menjadi tantangan tersendiri bagi seorang pengalihbahasa. Upaya untuk dapat memindahkan makna tersebut memungkinkan penerapan prosedur - prosedur tertentu pada proses alih bahasa. Prosedur yang sesuai setidaknya memberikan gambaran makna yang hampir sama pada BSu dan pembaca pada Bsa. Pada penelitiannya ditemukan prosedur calqued dan literal menjadi prosedur yang paling sering digunakan pada pengalihbahasaan istilah budaya Bali.

Alih bahasa tentunya tidak semudah yang dibayangkan. Apalagi perkembangan ilmu pengetahuan dan teknologi suatu negara dengan negara lain dipengaruhi berbagai faktor. Salah satu faktor penting adalah budaya. Budaya menjadi faktor yang harus mendapat perhatian dalam proses alih bahasa. Budaya dunia Barat yang identik dengan perkembangan ilmu pengetahuan dan teknologi sangat berbeda dengan budaya dunia Timur. Kondisi itu yang menjadi faktor penentu keberhasilan alih bahasa sebuah teks.

Budaya menjadi pertimbangan penting mengingat bahasa merupakan bagian dari budaya. Larson (1998: 470) mengungkapkan jika budaya merupakan kepercayaan, sikap, nilai, dan aturan yang dianut oleh suatu kelompok masyarakat. Kelompok masyarakat inilah yang secara turuntemurun melanjutkan budaya yang telah ada sejak dulu hingga kepada generasi berikutnya. Pemahaman antara satu kelompok masyarakat dan kelompok-kelompok masyarakat lain menyebabkan adanya perbedaan cara pandang terhadap kepercayaan, sikap, nilai dan aturan. Untuk itu, antara satu kelompok masyarakat dengan kelompok masyarakat lainnya akan memiliki cara pandang berbeda terhadap suatu pesan yang muncul dalam komunikasi. Perbedaan- 
perbedaan tersebut dikarenakan adanya pengalaman dan budaya yang berbeda.

Lebih lanjut Larson (1998: 3) menggambarkan alih bahasa sebagai proses memindahkan makna dari BSu ke BSa dengan mempertimbangkan pengubahan bentuk. Adapun tujuan pengubahan bentuk merupakan upaya mencapai kesepadanan yang menurut Larson (1998: 19) disebut alih bahasa idiomatis. Alih bahasa idiomatis merupakan alih bahasa yang sepadan, tidak terdengar aneh, dan menyesuaikan dengan struktur pada BSa. Hampir serupa dengan pernyataan tersebut, Nida dan Taber (1974: 13) mengungkapkan bahwa alih bahasa merupakan proses memproduksi kembali dalam $\mathrm{BSa}$ pesan yang dibawa BSu dengan kesepadanan alami yang paling dekat. Definisi itu juga menambahkan bahwa kesepadanan alami yang paling dekat disesuaikan pada tingkatan makna dan tingkatan gaya bahasa. Kesepadanan alami yang paling dekat menjadi tujuan seorang pengalih bahasa, yang pada definisi Larson (1998) lebih sering disebut alih bahasa idiomatis. Kesepadanan alami yang paling dekat maupun alih bahasa idiomatis menjadi tujuan seorang pengalih bahasa agar hasil alih bahasa yang telah dikerjakan tidak terdengar seperti sebuah alih bahasa namun telah menyesuaikan dengan struktur BSa.

Sehingga penggabungan atau kombinasi teknik juga dimungkinkan melalui 18 teknik yang disodorkan oleh Molina dan Albir (2002). Secara singkat Molina dan Albir memaparkan 18 teknik yang diaplikasikan dalam alih bahasa dan ke-18 teknik itu merupakan penggabungan secara keseluruhan dari teknik - teknik alih bahasa yang pernah dipaparkan oleh Vinay dan Darbelnet, Nida dan Taber, Margot, Vasquez Ayora, Delisle, dan Newmark (dalam Molina dan Albir, 2002). Sehingga dalam hal ini Molina dan Albir (2002) telah memahami adanya kemungkinan untuk menggabung atau mengkombinasikan sejumlah teknik yang sebelumnya dipaparkan oleh para ahli alih bahasa.

Beeckman dan Callow (dalam Larson, 1998: 179) memaparkan tiga teknik sederhana untuk mengatasi persoalan ketidaksepadanan leksikal dalam penerjemahan budaya.

1. Strategi yang menggunakan kata umum dengan frasa deskriptif atau pemaparan yang lebih rinci.

2. Strategi yang menggunakan kata pinjaman (loan word).
3. Strategi yang menggunakan penggantian istilah budaya (a cultural substitute).

Lebih lanjut Larson (1998: 180) memaparkan mengenai frasa deskriptif yang berhubungan dengan bentuk (form) dan fungsi (function). Dalam kaitan dengan tidak adanya suatu bentuk yang sepadan antara dua bahasa yang berbeda, maka solusi yang diberikan adalah memaparkan dengan frasa deskripsi. Penggunaan frasa deskripsi terhadap suatu kata atau istilah yang tidak sepadan dalam dua bahasa biasanya dikombinasikan dengan pemaparan mengenai bentuk maupun fungsi.

Dalam menentukan penjelas baik bentuk maupun fungsi, maka perspektif dari seorang penulis yang menentukan bagian yang digunakan. Pada satu sisi penjelasan bentuk dianggap penting dan pada suatu kesempatan penjelasan fungsi justru dianggap lebih penting. Larson (1998: 180) mencontohkan kata pensil dan kata anjing. Jika frasa deskripsi bentuk dianggap penting maka kata pensil dapat dipaparkan menjadi panjang, terbuat dari kayu, ujungnya lancip, dan biasanya terdapat penghapus di ujung lainnya. Namun, jika frasa deskripsi fungsi menjadi prioritas utama maka kata pensil dijelaskan menjadi sarana untuk menulis. Begitu juga halnya dengan kata anjing. Jika fungsinya menjadi hal utama, maka kata anjing dapat dideskripsikan sebagai binatang yang biasa diajak berburu atau menjaga rumah. Sedangkan jika bentuk dari anjing yang penting, maka bentuknya dapat dipaparkan melalui ukuran dan besar tubuhnya, warna kulitnya, maupun posisi bagian penting seperti mata, telinga, serta bahkan suara.

\section{METODE PENELITIAN}

Sumber data penelitian ini diambil dari media - media online berbahasa Inggris. Data yang digunakan merupakan data teks yang berisikan informasi terkait penggunaan istilah - istilah budaya Bali. Pemilihan data yang akan diambil melalui media online juga berdasarkan pertimbangan bahwa informasi tersebut lebih mudah diakses oleh pembaca asing. Yang menjadi fokus pada penelitian ini adalah teks yang berisikan informasi terkait budaya Bali dalam bahasa Inggris. Sehingga meskipun menerapkan teknik atau prosedur dalam alih bahasa, namun teks data pada artikel ini merupakan monolingual atau satu bahasa yaitu bahasa Inggris. Dalam hal ini data yang akan dipergunakan adalah data - data 
berupa konteks kalimat yang berisikan istilah Bali beserta penjelasan deskripsinya. Sehingga nantinya data - data yang berupa istilah budaya Bali serta penjelasannya akan lebih ditonjolkan dengan bentuk atau model huruf berbeda yang diikuti dengan konteks kalimat yang melingkupinya.

Metode yang akan digunakan pada pengumpulan data adalah metode simak. Dalam hal ini metode simak akan ditunjang dengan mengaplikasikan sejumlah teknik untuk mendapatkan data yang sesuai. Teknik - teknik yang akan diterapkan adalah teknik membaca rinci dengan tujuan mendapatkan data - data yang sesuai dengan keperluan penelitian. Selanjutnya teknik pencatatan yang berhubungan dengan pencatatan data - data yang terpilih. Sedangkan teknik lebih lanjut merupakan teknik klasifikasi berdasarkan pada konsep teori yang berhubungan dengan variasi pola deskripsi pada data.

Metode yang akan diterapkan pada proses analisa data adalah metode deskriptif kualitatif. Metode itu akan berhubungan erat dengan model deskripsi terhadap data - data terpilih secara kualitatif berdasarkan konsep teori deskripsi pada istilah budaya. Dalam hal ini teknik pemaparan secara deskriptif dengan ditunjang teori - teori deskripsi pada istilah budaya akan digunakan untuk menganalisa data. Sehingga nantinya akan diperoleh suatu model analisa atau kajian pola pola deskripsi yang digunakan pada pemaparan makna dari suatu istilah budaya khususnya budaya Bali.

\section{HASIL DAN PEMBAHASAN}

Pada bagian hasil dan pembahasan ini, terdapat 5 data yang berisikan informasi tentang istilah budaya Bali dalam konteks kalimat. Kelima data tersebut adalah lontar, kulkul, ogoh - ogoh, banjar, dan melasti. Masing - masing dari data berisikan istilah budaya Bali itu dianalisa secara lebih mendetail seperti di bawah ini.

Lontar (old manuscript) is the most iconic and unique manifestations of tangible and intangible cultural heritage preserved on Bali from the past through to the present day. The literature and religious lore of Balinese and ancient Javanese traditions have been reproduced through the centuries via a learned tradition of writing and reading texts on lontar.

(data 1)

\begin{abstract}
Taken from:
https://balicultureinformation.wordpre ss.com/2015/12/05/lontar-balinesemanuscript-which-contain-a-varietyof-aspects-of-human-life/
\end{abstract}

Istilah budaya Bali lontar yang terdapat pada data 1 di atas adalah istilah budaya yang berkaitan dengan kelengkapan masyarakat Bali. Kelengkapan yang dimaksud adalah hal - hal yang berhubungan dengan keseharian maupun ritual masyarakat Bali. Istilah lontar mempunyai keterkaitan dengan beragam aspek kehidupan masyarakat Bali mulai dari keseharian, upacara, hingga pada pengobatan tradisional. Pada teks bahasa Inggris di data 1, istilah tersebut mendapat frasa deskripsi old manuscript.

Dengan frasa deskripsi old manuscript maka istilah budaya lontar dijelaskan dengan menekankan pada frasa deskripsi kombinasi bentuk. Kombinasi penjelas bentuk dapat dilihat dari frasa old manuscript. Jika dimaknai secara sederhana, frasa deskripsi old manuscript hanya menjelaskan bahwa istilah budaya lontar merupakan manuskrip - manuskrip yang digunakan pada masa lalu. Sehingga pola deskripsi yang muncul adalah pola deskripsi kombinasi bentuk. Istilah budaya lontar dijelaskan secara bentuk menjadi old manuscript.

Penggunaan pola deskripsi kombinasi bentuk untuk menjelaskan istilah budaya lontar dengan old manuscript tidak memunculkan makna secara keseluruhan. Makna istilah lontar dengan frasa deskripsi old manuscript hanya mengacu pada bentuk serta waktu penggunaan manuskrip yang dimaksud. Padahal secara budaya, istilah lontar justru memiliki pemaknaan yang kompleks menyeluruh. Istilah lontar tidak semata hanya manuskrip lama, namun juga berisikan ajaran ajaran mulai dari keagamaan, kehidupan sehari hari, hingga kedokteran tradisional. Dengan begitu, pola deskripsi kombinasi bentuk old manuscript belum memunculkan keseluruhan makna dari istilah budaya lontar.

Kulkul is a big bell made of wood or bamboo use by various social organization of Balinese society or known as Balinese bell. Like a bell it is used to indicate time of gathering, ceremony, and in the past to call the people during a strain time resulted by conflict, or criminal. Organization in Bali 
are various based on tradition, profession or hobby.

(data 2)

$$
\begin{aligned}
& \text { Taken from: } \\
& \text { https://www.balitouring.co } \\
& \text { m/bali_articles/kulkul.htm }
\end{aligned}
$$

Yang justru menarik untuk dianalisa lebih lanjut adalah istilah budaya kulkul pada data 2 di atas. Istilah kulkul merupakan bagian dari kelengkapan keseharian masyarakat Bali. Pada data 2, frasa deskripsi yang digunakan dalam teks berbahasa Inggris adalah Balinese bell. Istilah budaya kulkul dengan frasa penjelas Balinese bell mengindikasikan adanya kombinasi bentuk dan fungsi, namun tidak secara eksplisit muncul dalam frasa yang dimaksud.

Secara rinci, frasa deskripsi Balinese bell memaparkan bentuk. Dalam hal ini penggunaan kata bell mencerminkan bentuk bel yang digunakan hampir sebagian besar orang di dunia. Secara bentuk, hampir semua orang mengetahui tentang bel. Selain itu, setiap orang juga memahami fungsi dari bel. Meskipun hal tersebut tidak dijelaskan. Saat seseorang menjelaskan tentang bel, maka lawan tutur pasti memahami bentuk dan selanjutnya fungsi dari bel. Begitu juga dengan kulkul yang dijelaskan dengan Balinese bell. Penggunaan frasa deskripsi Balinese bell mencirikan bel yang khusus digunakan oleh masyarakat Bali. Dari penekanan tersebut tentunya akan muncul pemahaman tentang fungsi. Secara kebetulan, teks penjelas dalam bahasa Inggris di data 2 turut membantu penjelasan lebih lanjut frasa deskripsi Balinese bell. Sehingga jika disimpulkan, istilah kulkul yang dijelaskan dengan frasa Balinese bell mempunyai kombinasi bentuk dan fungsi. Hanya, pemahaman tentang fungsinya muncul secara implisit dan dipaparkan dalam kalimat penjelas selanjutnya.

Meskipun begitu, frasa deskripsi Balinese bell masih belum mendeskripsikan bentuk bel yang digunakan oleh masyarakat Bali. Istilah kulkul seharusnya bisa lebih dideskripsikan sebagai bel besar yang menjadi tradisi adat masyarakat Bali dalam beraktivitas di lingkungannya. Jadi, pemaknaan bell yang munculkan tidak semata mata adalah bel yang biasa digunakan oleh semua orang, namun justru mempunyai keunikan dalam hal ukuran bel. Apalagi mengingat fungsinya yang penting bagi masyarakat Bali.
Entire villages are marching past me carrying enormous Ogoh Ogoh demons towards their grave. It is the eve of Nyepi, the Balinese New Year. The children of every village have spent weeks constructing these paper monsters. Each one represents a vice: lust, alcohol, avarice, or greed. They are comical and frightening, familiar and hideous. Big tits. Greedy eyes.

(data 3)

$$
\begin{aligned}
& \text { taken from: } \\
& \text { http://www.fivelements.org/en/abo } \\
& \text { ut-us/living-in-harmony- } \\
& \text { blog/item/60-healing-with-five- } \\
& \text { balinese-elements }
\end{aligned}
$$

Istilah budaya Bali yang berkaitan dengan kelengkapan kegiatan terdapat pada data 3. Istilah ogoh - ogoh adalah rangkaian dari kegiatan hari raya Nyepi. Umumnya, sehari sebelum pelaksanaan hari raya Nyepi dilaksanakan pawai ogoh - ogoh. Hal itu ditujukan sebagai bentuk pengusiran pengaruh - pengaruh buruk pada lingkungan manusia. Pada teks bahasa Inggris data 3, istilah ogoh - ogoh dijelaskan dengan frasa deskripsi paper monsters.

Jika diklasifikasikan, penggunaan frasa deskripsi paper monsters mengacu pada bentuk dari ogoh - ogoh. Sehingga penjelasan frasa deskripsi yang digunakan merupakan frasa deskripsi kombinasi bentuk. Penekanan bentuk paper monsters lebih mudah untuk dijabarkan mengingat ketiadaan bentuk leksikal istilah ogohogoh pada bahasa Inggris. Penjelasan frasa deskripsi kombinasi bentuk menjadi pilihan guna memberikan pemahaman terhadap istilah ogoh ogoh pada pembaca asing.

Dengan menerapkan frasa deskripsi paper monsters, sesungguhnya makna ogoh - ogoh masih belum seluruhnya dapat dipahami. Apalagi jika memperhatikan bentuk ogoh - ogoh yang cenderung besar, tinggi, dan menyeramkan sebagai perwujudan makhluk kasat mata yang memiliki pengaruh buruk bagi manusia. Dalam hal ini, pola deskripsi bentuk paper monsters masih belum memberikan pemahaman menyeluruh terhadap makna istilah ogoh-ogoh.

Leading up to the Saka New Year, village meeting halls (known as Banjar) across Bali will be hard at work preparing their Ogoh Ogohs for the island-wide street 
parades. The Ogoh-Ogohs are papier-mâché effigies inspired by Balinese Hindu mythological demonic beings, and are intricately made from colored papers, mirrors, suede, tinsel, bamboo, and many other materials.

(data 4)

taken from: http://padmaresortubud.com/blog/b ali-gears-welcome-saka-new-year

Sementara itu, data 4 berisikan istilah budaya yang berkaitan dengan tempat. Yang dimaksudkan dengan tempat adalah banjar atau bale banjar. Istilah banjar atau bale banjar mempunyai fungsi sebagai tempat berkumpul suatu kelompok masyarakat untuk membicarakan berbagai hal. Secara umum, dalam suatu desa tradisional di Bali terdapat sedikitnya satu banjar atau bale banjar. Dalam teks bahasa Inggris digunakan frasa deskripsi village meeting hall.

Jika memperhatikan secara lebih rinci, pemakaian frasa deskriptif village meeting hall untuk menjelaskan istilah banjar adalah bentuk kombinasi. Bentuk kombinasi yang dimaksud merupakan kombinasi antara bentuk dan fungsi dari suatu istilah. Dalam hal ini, frasa village meeting hall mempunyai posisi menjelaskan bentuk dan fungsi pada saat bersamaan. Secara bentuk, penggunaan kata hall mengacu kepada pemahaman umum terhadap suatu tempat yang luas dan biasanya digunakan untuk pertemuan. Sedangkan secara fungsi, frasa village meeting memberikan pemahaman tentang fungsi yang berkaitan dengan pertemuan - pertemuan desa. Mengingat desa adalah bagian institusi paling penting di Bali, maka penggunaan kata village juga menjadi penekanan pada teks bahasa Inggris. Tentunya dalam hal ini lebih cenderung pada pertemuan yang dilaksanakan oleh warga desa. Dengan demikian, secara keseluruhan istilah banjar dijelaskan dengan frasa deskripsi village meeting hall yang mengkombinasikan bentuk dan fungsi dalam pemahamannya.

Secara makna, istilah budaya banjar yang dijelaskan dengan frasa deskripsi bentuk dan fungsi village meeting hall telah memunculkan keseluruhan makna. Makna asal istilah banjar sebagai tempat pertemuan warga suatu desa di Bali dapat dijelaskan dengan frasa deskripsi village meeting hall. Sehingga pembaca asing dapat memahami melalui penggunaan kata yang masih dekat dengan budayanya. Dalam hal ini penggunaan kata hall yang menjadi acuan bagi pembaca asing.

Hailing from across the regency and surrounding cities, such as Magelang, Sragen, Bantul, Kulon Progo and Surakarta, the Hindu adherents flocked to the seashore to participate in melasti, a Hindu ritual held to cleanse the soul and nature. The purification ritual was performed ahead of Nyepi, the Hindu Day of Silence, a national holiday that falls on March 28 this year.

\section{(data 5)}

Data 5 berisikan istilah budaya Bali melasti. Istilah itu dalam teks berbahasa Inggris dijelaskan dengan frasa deskripsi purification ritual. Dalam budaya Bali, istilah melasti merupakan rangkaian dari kegiatan hari raya Nyepi. Istilah melasti dikaitkan dengan penyucian dan pembersihan benda - benda suci di pura - pura di suatu wilayah desa. Penyucian benda - benda suci atau sakral itu dipercaya sebagai usaha untuk menghanyutkan kotoran - kotoran dengan menggunakan air kehidupan. Dalam hal ini air kehidupan yang digunakan adalah air laut maupun air danau.

Frasa deskripsi the purification ritual berhubungan dengan penjelasan istilah budaya melasti. Dalam hal ini, frasa deskripsi the purification ritual menjelaskan bentuk kegiatan yang berhubungan dengan istilah melasti. Sehingga frasa deskripsi yang digunakan adalah frasa deskripsi kombinasi bentuk. Istilah budaya melasti tidak memiliki kesepadanan leksikal pada bahasa Inggris. Untuk memberikan pemahaman terhadap istilah melasti, penulis menggunakan frasa deskripsi kombinasi bentuk. Kombinasi bentuk dapat dilihat pada penggunaan kata ritual yang mempunyai makna upacara atau kegiatan tradisional. Dengan demikian, keseluruhan frasa the purification ritual mencirikan bentuk dari suatu upacara.

Memperhatikan segi makna, maka istilah budaya melasti yang dijelaskan menggunakan frasa deskripsi kombinasi bentuk the purification ritual 
mempunyai kesepadanan pemahaman. Kesepadanan pemahaman terhadap kegiatan penyucian atau pembersihan yang berhubungan dengan melasti. Sehingga penggunaan frasa deskripsi the purification ritual sudah memberikan penjelasan yang sepadan terhadap istilah budaya melasti.

\section{SIMPULAN}

Dari uraian sebelumnya dapat disimpulkan bahwa istilah - istilah budaya Bali yang terdapat pada media - media online berbahasa Inggris mempunyai kecenderungan menggunakan pola deskripsi dalam memberikan pemaknaan. Pola deskripsi yang dominan digunakan adalah pola deskripsi berkaitan dengan bentuk. Pola deskripsi bentuk tersebut memberikan gambaran kepada pembaca dengan budaya berbeda tentang istilah budaya Bali yang dijelaskan. Selain deskripsi bentuk, yang juga digunakan adalah pola deskripsi yang mengkombinasikan bentuk dan fungsi dari suatu istilah budaya Bali. Dalam hal ini pembaca memperoleh dua informasi terkait bentuk dan fungsi dari suatu istilah budaya Bali.

\section{DAFTAR PUSTAKA}

Larson, Mildred L. 1998. Meaning-Based Translation, A Guide to Cross-Language Equivalence. Oxford: University Press of America.
Mahsun, M.S., Prof. Dr. 2005. Metode Penelitian Bahasa, Tahapan strategi, metode, dan tekniknya. Jakarta: PT RajaGrafindo Persada.

Molina, L dan Albir, A.H. 2002. "Translation Technique Revisited: A Dynamic and Functionalist Approach". Dalam Meta, Vol. XLVII, No. 4. Hal. 499 - 512. http://www.erudit.org

Newmark, Peter. 1988. A Textbook of Translation. Washington: Longman Pearson Education

Parthama, I Gusti Ngurah. 2006. "The Translation of Balinese Religious Terms". (Tesis). Denpasar: Program Studi Linguistik, Program Pascasarjana, Universitas Udayana.

Parthama, I Gusti Ngurah. 2016. Kesalahan Penggunaan Bahasa Inggris di Masyarakat: Kajian Sosiogramatika. Laporan Penelitian Hibah Unggulan Program Studi (HUPS) Lembaga Penelitian dan Pengabdian kepada Masyarakat (LPPM) Universitas Udayana.

Setianingsih, Alit Ida. 2003. "Some Alternative Ways of Establishing Lexical Equivalences of Balinese Cultural Terms in English. (Tesis). Denpasar: Program Studi Linguistik, Program Pascasarjana, Universitas Udayana. 